\title{
Stroke in Renaissance Time: The Case of Francesco I de' Medici
}

\author{
Francesco Arba $^{\text {a }}$ Domenico Inzitari ${ }^{a}$ Henry Joseph Macaulay Barnett ${ }^{c}$ \\ Donatella Lippi ${ }^{\text {b }}$ \\ Departments of a Neurological and Psychiatric Sciences and ${ }^{\mathrm{b}}$ Anatomy, Histology and Legal Medicine, University of \\ Florence, Florence, Italy; ${ }^{C}$ Robarts Research Institute, University of Western Ontario, London, Ont., Canada
}

\section{Key Words}

Disability $\cdot$ Renaissance $\cdot$ Medici family

\begin{abstract}
Francesco I de' Medici (1541-1587), the second Grand Duke of Tuscany, was one of the members of the Medici family who ruled Florence during the centuries of the Renaissance. When, in 1857, all members of the Medici family were exhumed and definitively buried in the place where they still lie buried today, a painter, Giuseppe Moricci (Florence 18061879), who attended the ceremony, depicted the corpse of Francesco I in a perfect state of preservation. The painting shows a right spastic hemiparesis with a facial droop, a clawhand appearance, the right shoulder internally rotated, the calf muscle wasted and the clubfoot confirmed by an orthopedic footwear in the coffin. The hemiparesis and consequent disability were likely concealed when Francesco I was alive, since in official portraits the Grand Duke appeared in perfect physical condition. However, chronicles reported that he had suffered from malaria and syphilis. Later in his life, temper and behavioral changes as well as emotional instability were documented, together with handwriting deterioration and seizures. We postulate that Francesco I had suffered from a stroke consequent to syphilis, a new aggressive and rapidly spreading infectious disease at that time in Italy. Francesco's governmental skills were presumably altered
\end{abstract}

due to these diseases. Disability consequent to stroke was likely concealed by official portrayers and biographers of Francesco I during his life, consistent with the King's two bodies theory common since the Middle Ages: while the King's physical body is destined to die, the political one is everlasting. Infectious diseases have remained a leading cause of stroke in underdeveloped countries until recently, but noncommunicable causes are now prevailing worldwide.

Copyright $\odot 2012$ S. Karger AG, Basel

\section{Introduction}

Brain vascular diseases have played an important role in the history of nations. In recent times, for example, $\mathrm{N}$. Lenin and the Field Marshal P. Von Hindenburg suffered from a disease with a stuttering course, and culmination in a major stroke, which probably had consequences for the fate of world events in the 20th century [1]. Among the members of the Medici family who ruled Florence during the golden centuries of the Renaissance, the Grand Duke Francesco I may represent a similar case. Born in 1541, Francesco I died under mysterious circumstances in 1587 [2]. A picture of his body, painted when it was exhumed 300 years after his death (1857), shows clear signs of a right spastic hemiparesis, possibly

\section{KARGER \\ Fax +4161306 1234 \\ E-Mail karger@karger.ch}

www.karger.com
(C) 2012 S. Karger AG, Basel

$1015-9770 / 12 / 0336-0589 \$ 38.00 / 0$

Accessible online at:

www.karger.com/ced
Domenico Inzitari

Department of Neurological and Psychiatric Sciences

University of Florence, Viale Morgagni 85

IT-50134 Florence (Italy)

Tel. +39 055794 7441,E-Mail inzitari@unifi.it 
Fig. 1. Watercolor of Francesco I by Moricci. Giuseppe Moricci (1806-1879). Gabinetto Fotografico Uffizi 306165. Published with kind permission of the Ministero per i Beni e le Attività Culturali.

residual to a stroke event. None of his portraits or biographical documents give any hint suggesting that he had suffered from a neurological disease. We report and discuss information and documents illustrating his medical history, hypothetical causes of the stroke, the potential impact of this disease on his governing skills, and the fact that his disability was likely concealed when he was alive.

\section{Analysis of the Painting and Historical Documents}

When, in 1857, all members of the Medici family were exhumed and definitively buried in the place where they still lie buried today, a painter, Giuseppe Moricci (Florence 1806-1879), who attended the ceremony, depicted the corpse of Francesco I, and was astonished by his perfect state of preservation, possibly due to the arsenic poisoning as cause of death of Francesco I [2]. As a matter of fact, Francesco I de' Medici and his second wife Bianca Cappello died within a few hours of each other, with symptoms consistent with acute arsenic poisoning. Francesco's brother, Cardinal Ferdinando, was accused of poisoning them because of his hatred towards Bianca and his aspiration to be Governor of Tuscany. The official verdict attributed their deaths to malaria [3]. After a recent further exhumation carried out in the framework of the Medici Project [4, 5], a historic-medical investigation of the corpses of the Medici Grand Dukes, significant levels of arsenic were detected in some organic fragments of Francesco's and Bianca's bowels, confirming that the Grand Duke and his wife were poisoned [2]. It is well known that tissue dehydration caused by arsenic helps in preventing putrefaction.

Some details of the Moricci's watercolor, which is preserved in the collection of Gabinetto dei Disegni e Stampe of the Uffizi Gallery No. 18987 (Florence) (fig. 1), combined with the elements taken from the literary documents [3], suggested to reconsider Francesco's state of health at death: the Grand Duke's body, dressed in his funeral robe, is lying in the coffin, with his hairless head resting on a pillow, slightly turned to the right. A facial droop may be noted, the hand has a claw appearance, and the shoulder is internally rotated. The calf muscle is wasted and the clubfoot seems to be confirmed by an orthopedic footwear in a corner of the coffin. This merciless representation of Francesco's physical aspect is an exceptional case, and it can be explained only because it was executed after the Grand Duke's death and after the end of the dynasty. During Francesco's life, he was portrayed by the most important artists of the time, who would never have dared to highlight the defects of such an important commissioner. However, critically examining the portraits of Francesco alive it is possible to observe that when standing, the Grand Duke is usually leaning on a support (fig. 2). This stereotypical representation could suggest the artists' intention to conceal Francesco's physical defects.

However, literary documents report a natural birth [6] and a normal physical development [3] and do not mention any sudden illness or accident. He probably was hyperuricemic, as many members of the Medici family were [7], and had contracted malaria [8], which was endemic in Tuscany at that time. The chronicles [9] reported that, when he was 20, Francesco contracted syphilis during a journey to Rome. Another clue resulting from the archive documents is the Grand Duke's handwriting, which progressively worsened starting from 1563, becoming illegible in the last years of his life [9] (fig. 3). The letters look 
2

Fig. 2. Portrait of Francesco I. Scipione Pulzone, post 1584, oil on wood, Cerreto Guidi, Villa Medicea, Museo Storico della Caccia e del Territorio, inv. 1890 n. 5454. Published with kind permission of the Ministero per i Beni e le Attività Culturali. Fig. 3. Worsening in handwriting during the years: 1563 (a), 1568 (b), 1576 (c), 1579 (d) [9]. Published with kind permission of the Ministero per i Beni e le Attività Culturali.

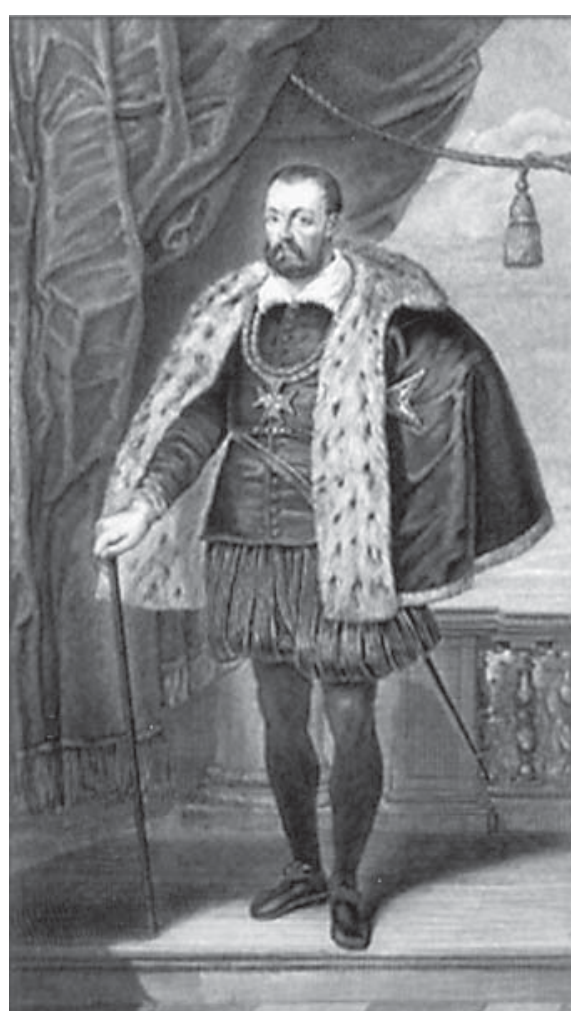

3
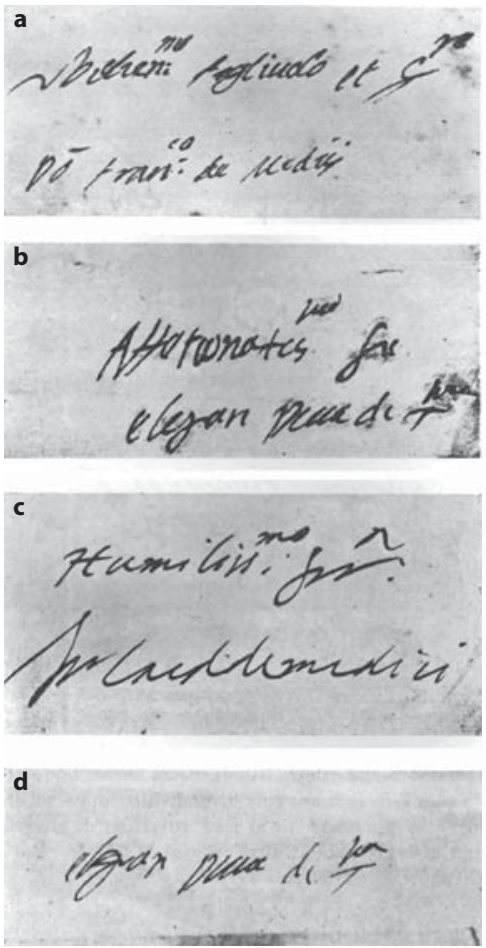

small and unsteady, and the words are difficult to read. Signatures in 1576 and 1579 are unreadable. This could be attributed to either a deteriorating stepwise process or to the increasing spasticity in the hand. Francesco's behavior and temper were distinctive: he was a dark, introverted man, famous for preferring art and alchemy to government affairs. Both mood and behavior progressively deteriorated over time: his lifestyle became eventually messy, his wishes ungovernable. His behavior was characterized by a remarkable emotional instability, and short temper. As an event testifying Francesco I's bad character, one of his biographers [10] reported a paramount episode: his stableman was instantaneously killed by him just because he had accidentally bumped into him. Finally, from 1576, Francesco I started to manifest seizures [11].

\section{Disease Hypotheses}

From the faithful representation of Moricci's watercolor, at a certain time of his life Francesco I was likely hidden by a right spastic hemiparesis, consistent with a left cerebral hemisphere lesion. He was right-handed [3], and, since no speech disorders result from any document reporting about him, a lesion seated in the corona radiata or in the internal capsule can be postulated, rather than a cortically seated one. The hypothesis that the lesion could have been consequent to cerebral palsy is the least probable. In this case, symptoms usually manifest within 2 years of life $[12,13]$, and lead to childhood disability. Speech may be spared due to the reorganization of the speech area during early development $[14,15]$. The progressive worsening of his handwriting supports the hypothesis that fine motor skills were normal until a certain time, and were lost in the adulthood, but we can not be sure that disuse contractures were not the cause. No head trauma or symptoms suggesting a brain tumor are available in the documents. Considering the whole historical information, we advance the hypothesis that the Grand Duke suffered from a stroke that was eventually concealed by official reports in order to protect his political image. Regarding stroke risk factors and comorbidities predisposing to stroke, it has to be noted that in general accurate information about conventional cardiovascular risk factors or comorbidities are generally lacking in documents of that age. However, there are several indirect clues. (1) Hypertension: after the second exhumation car- 
ried out in 1947 by a group of anthropologists, Francesco I's remains were deprived of every tissue and hair [5]. Actually, the team of the Medici Project had at their disposal almost exclusively Francesco's bones. The vertebral column did not show any indirect sign of hypertension [4], i.e. the lack of osteophytes on the left side of the column, a finding held to reflect increased aortic pulsation. (2) Data about hyperuricemia, which is known for being associated with an increased risk of hypertension [16] and with higher stroke incidence and mortality, have been consistently reported among Medici family members [17]. (3) Metabolic syndrome: portraits show the Grand Duke as obese, and chronicles report a lifestyle at risk of developing such a syndrome. There are no other hints signifying diabetes, cardiac disease, or atherosclerosis. (4) Family history of stroke: Francesco I's father, Cosimo, died of stroke sequelae at the age of 48 [18]. The majority of the other family members had died from infectious diseases [19]. (5) Infections: in pre-antibiotic era, a pivotal risk factor for cerebrovascular diseases was infection, which can cause stroke through several mechanisms [20]. A widespread infective pathology in the Renaissance time in Italy was malaria. The increased stroke risk in malaria is likely limited to immunocompromised patients [21]. Another infectious disease that may cause vascular brain lesions is syphilis. It appeared in Europe at the end of the 15th century [22]. At first, the disease was more virulent and had almost always a fatal progressive course [23]. In the 16th century, the natural history of the disease changed, becoming less virulent and more insidious [22]. Neurovascular syphilis may occur from a few months to many years after the primary infection [24]. In $25 \%$ of cases, vascular syndromes associated with syphilis have a progressive course: it may take weeks or months until the syndrome is identified as of cerebrovascular origin [25]. More than half of these patients present with a syndrome referable to a superficial or deep middle cerebral artery territory lesion [24]. In the paretic neurosyphilis form, both psychic and cognitive functions may be affected, together with a decline in personal appearance. Handwriting abnormalities were once believed to be nearly diagnostic of this disorder [25]. Epileptic seizures may occur in one-fourth of cases of neurosyphilis [26] and are more frequent in the meningovascular or the paretic forms [24]. Finally, the baldness: alopecia is one of the cutaneous symptoms of syphilis [27].

In economically low developed countries, syphilis has remained, until recently, a frequent cause of stroke [28]. However, with the economy development, while communicable diseases are better controlled, abnormal dietary habits, smoking, or alcohol consumption tend to increase, leading towards predominance of conventional stroke causes [29].

\section{Did Neurological Disease Influence Francesco l's Governance?}

Answering the question whether the cerebrovascular disease could have influenced Francesco's government, Francesco had a tyrannical behavior, like his father. But while Cosimo had managed to defend the political independence of his reign, Francesco was prone to satisfy the interests of the Emperor, Ferdinand I of Habsburg, who was his father-in-law. In order to pay large sums to the empire, he was forced to exact conspicuous taxes, inducing a lot of complaints among citizens. Moreover, he neglected government duties, preferring to dedicate his time to chemistry and alchemy instead of political concerns. He spent many hours in his private laboratory (the Studiolo) seated in Palazzo Vecchio, the sumptuous political palace in Florence. One can argue that his peculiar personality, likely combined with physical problems, made his leadership definitely less efficient when compared to the other Medici family governors of Florence.

\section{How Politicians Tend to Conceal Disability}

In ancient times, disability was viewed as detrimental to a public person. Church and people leaders always had to demonstrate to be free of any physical defect as disability was equated with incompetence: a disabled person was assumed to be weak, dependent and unfit for office. Starting from the middle centuries of the Middle Ages, a concept became popular supporting the King's two bodies theory [30]: the King has a physical body, which is destined to die, but he also has a political body, which is everlasting. The physical body of the King, personification and living metaphor of the body of the community, had to maintain his perfect health [31]. Although indirectly, this could support the hypothesis that the disability of Francesco I was concealed during his life.

Even in recent times, although photography has replaced painting, there are examples of hidden disability of political leaders confirming the importance of the 'two bodies'. For instance, Franklin D. Roosevelt, who had a lower limb paralysis and needed a wheelchair, for a long time succeeded in concealing his disability in his public apparitions [32]. 


\section{Conclusions}

Francesco I's hemiparesis, disclosed by the Moricci's watercolor, suggests that he had likely suffered from a stroke with stuttering course during his life. The discrepancy between the official representations of Francesco I and Moricci's watercolor can be attributed to a common behavior of the artists of the time. In our interpretation, the disease was probably caused by cerebrovascular complications of a new infectious disease at that time in Italy, namely syphilis. The same pathology led to the other neurological consequences, such as personality and behavioral changes, impairment in handwriting, and epilepsy. Neurological disability possibly negatively affected Francesco I's governance. Moreover, disability consequent to stroke had probably been concealed during his life, similarly to what has happened for other public persons over centuries, and this was consistent with the ancient political philosophical concept of the King's two bodies.

\section{References}

1 Friedlander WJ: About three old men: an in quiry into how cerebral arteriosclerosis has altered world politics: a neurologist's view. Stroke 1972;3:467-473.

-2 Mari F, Polettini A, Lippi D, Bertol E: The mysterious death of Francesco I de' Medici and Bianca Cappello: an arsenic murder? BMJ 2006;333:23-30.

3 Pieraccini G: La stirpe de' Medici di Cafaggiolo (ed 1). Firenze, Vallechi, 1924.

4 Lippi D: The Medici project. Herald Eur 2006;3:122-125.

5 Lippi D: Illacrimate sepolture. Curiosità e ricerca scientifica nella storia delle riesumazioni dei Medici (ed 2). Florence, Florence University Press, 2008.

6 ASFi, MDP, filza 600 c. 5 .

7 Costa A, Weber G: Le alterazioni morbose del sistema scheletrico in Cosimo dei Medici il Vecchio, in Pietro il Gottoso, in Lorenzo il Magnifico, in Giuliano Duca di Nemours. Arch Vecchi Anat Patol Med Clin 1955;23: $1-69$.

$\checkmark 8$ Fornaciari G, Giuffra V, Ferroglio E, Bianucci R: Malaria was 'the killer' of Francesco I de' Medici (1531-1587). Am J Med 2010;123: 568-569.

9 Fenyes G: Nuovi contributi sulla morte di Francesco e Giovanna de' Medici. Riv Storia Sci Med Nat 1937;XIX:1-23.

10 Bibl Riccard, Cod Rice. 1851-52 Diario Istorico Fiorentino. Arch D Stato Misc Manoscr, p 166.

11 Saltini GE: Della morte di Francesco I de' Medici e di Bianca Cappello. Arch Storico Italiano, Nuova Serie 1863;XVIII:19-79.
12 Koman LA, Smith BP, Shilt JS: Cerebral pal sy. Lancet 2004;363:1619-1631.

13 Kuban KCK, Leviton A: Cerebral palsy. N Engl J Med 1994;333:188-195.

14 Staudt M, Grodd G, Niemann D, Wildgruber D, Erb M, Krägeloh-Mann I: Early left periventricular brain lesions induce right hemispheric organization of speech. Neurology 2001;57:122-125.

15 Staudt M: Reorganization after pre- and perinatal brain lesions. J Anat 2010;217:469477.

16 Krishnan E, Kwoh CK, Schumacher HR, Kuller L: Hyperuricemia and incidence of hypertension among men without metabolic syndrome. Hypertension 2007;49:298-303.

-17 Kim SY, Guevara JP, Mi Kim K, Choi HK, Heitjan DF, Albert DA: Hyperuricemia and risk of stroke: a systematic review and metaanalysis. Arthritis Rheum 2009;61:885-892.

18 Alberi E: Relazioni degli ambasciatori veneti al Senato. Firenze, Società editrice fiorentina, 1839-63, serie II, vol 2, p 375.

19 Lippi D, Matucci Cerinic M, Albury WR, Weisz GM: Longevity and causes of death of adult males in the Medici Di Bicci family. Fam Hist 2009;34:243-250.

20 Ionita CC, Siddiqui AH, Levy EI, Hopkins LN, Snyder KV, Gibbons KJ: Acute ischemic stroke and infections. J Stroke Cereb Dis 2011;20:1-9.
21 Idro R, Jenkins NE, Newton CR: Pathogenesis, clinical features, and neurological outcome of cerebral malaria. Lancet Neurol 2005;4:827-840.

22 Tognotti E: The rise and fall of syphilis in Renaissance Europe. J Med Humanit 2009; 30:99-113.

23 Fracastoro G: Prose Treatise on Syphilis (transl. F. Pellegrini). Verona, Biblioteca Capitolare, 1939.

24 Merritt HH, Adams RD, Solomon HC: Neurosyphilis. New York, Oxford University Press, 1946.

25 Simon RP: Neurosyphilis. Arch Neurol 1985; 42:606-613.

26 Sinha S, Harish T, Taly AB, Murthy P, Nagarathna S, Chandramuki A: Symptomatic seizures in neurosyphilis: an experience from a University Hospital in South India. Seizure 2008;17:711-716.

27 Cuozzo DW, Benson PM, Sperling LC, Skelton HG 3rd: Essential syphilitic alopecia revisited. J Am Acad Dermatol 1995;32:840843

28 Timmermans M, Carr J: Neurosyphilis in the modern era. J Neurol Neurosurg Psychiatry 2004;75:1727-1730.

29 Norrving B: World stroke day editorial. Int J Stroke 2011;6:377.

30 Kantorowicz I: The King's Two Bodies. A study in Mediaeval Political Theology. Princeton, Princeton University, 1957.

31 Biblioteca Mediceo Laurenziana, ms Plut 76.77 .

32 Gallagher HG: FDR's Splendid Deception. Arlington, Vandemere Press, 1994. 